Article

\title{
The Attitude of Tourist Destination Residents towards the Effects of Overtourism-Kraków Case Study
}

\author{
Adam R. Szromek ${ }^{1}\left(\mathbb{D}\right.$, Zygmunt Kruczek $^{2, *} \mathbb{D}$ and Bartłomiej Walas ${ }^{3}$ \\ 1 Department of Organization and Management, Institute of Economy and Informatics, Silesian University of \\ Technology, Akademicka 2A, 44-100 Gliwice, Poland; szromek@polsl.pl \\ 2 Department of Tourism and Recreation, University School of Physical Education, 31-517 Kraków, Al. Jana \\ Pawła II 78, Poland \\ 3 Department of Tourism and Recreation, The University College of Tourism and Ecology, 34-200 Sucha \\ Beskidzka, Zamkowa 1, Poland; bwalas@onet.eu \\ * Correspondence: zygmunt.kruczek@awf.krakow.pl; Tel.: +48-602-126-282
}

Received: 27 November 2019; Accepted: 24 December 2019; Published: 26 December 2019

check for updates

\begin{abstract}
Scientific research into the effect of tourist traffic in a tourist area have shown that the excessive concentration of tourist traffic leads to overcrowding in attractive locations, over-advertising, and aggressive commercialization, which lower the aesthetic quality of tourists' experiences and result in the degradation of natural and cultural resources. The effect of excessive tourist numbers is an increase in the price of services, rental fees, and real estate. In historical cities, it causes the gentrification of historical districts. One of the social effects of an increase in tourist numbers is a change in attitude amongst residents towards tourists. This change is dependent on how residents perceive the positive and negative effects of tourism. The appearance of a negative attitude among residents towards tourists is a result of exceeding the social carrying capacity limits, that is, the ability to accept changes as they take place. This article assesses the attitudes of residents and tourist service providers in Kraków with regard to increasing tourist traffic and the ongoing process of change in the cityscape leading to the gentrification of districts most often visited by tourists. On the basis of a study of 518 respondents, including 371 city residents and 147 representatives of the tourist industry (hotel owners, restaurateurs, and tourist service providers), an assessment is made of their attitudes towards the specific problems of tourism development in Kraków. The research results indicate a variety of attitudes among interested parties, thus confirming the research hypothesis that actors display varied approaches with regard to the further development of tourism in Kraków. The conclusions drawn could prove useful in shaping the city's policy on tourism according to the idea of sustainable development, by taking into consideration the current and future needs of all interested parties.
\end{abstract}

Keywords: sustainability; overtourism; Kraków; Doxey index; attitudes; residents; service providers

\section{Introduction}

Scientific research into the development of tourism generally looks from the perspective of the positive effects of such development. This research often omits the negative impact of tourism, which may only appear after a long period of time and which can result in uneven development among various groups within the local community. One example of this is the term 'overtourism', developed in the last few years in media reports on the negative impact of mass tourism on host communities and/or the natural environment. The definition of overtourism was formulated in UNWTO documents in 2018 and reads "the impact of tourism on a destination, or parts thereof, that excessively influences perceived quality of life of citizens and/or quality of visitors' experiences in a negative way" [1]. A tourist area has its limitations that result from the usable area available and its reaction to tourist traffic [2]. A key 
problem is defining the permissible size of traffic, above which it may be considered excessive. For cities that are large centers of tourism and are faced with an invasion of tourists, proposed indicators define the optimal level of socio-psychological capacity [3].

Numerous studies have confirmed that the behavior of visitors, the length of their stay, the volume of tourists and the type of tourism are in fact equally as important as the number of tourists [4]. While the influence of tourism on the physical environment is relatively easy to define, it is decidedly more difficult to assess the social effects of an influx of tourists. A concept based on the host community's tolerance towards tourists is not only subjective but is also difficult to measure. The level of tolerance among residents towards an influx of tourists varies depending on local and private interests $[5,6]$.

Overtourism and its related problems can be observed in many European cities, such as Venice, Florence, Barcelona, Rome, Prague, Dubrovnik, and Ljubljana [7]. In Poland, one example of the evolving role of tourism in city life is Kraków, a city that was added to the UNESCO list of Cultural and Natural World Heritage Sites in 1978 [8] and which is a recognized brand in the national and international tourist market. Without a doubt, the growing number of tourists encourages a city's growth, increases its budget, and distinguishes it on the tourism market, but the question arises-what burden does this bring for the inhabitants? The ongoing process of change undoubtedly results in a lowering of the quality of life but also causes a breakdown in social ties and a weakening of the local sense of identity. Residents lose their significance in their little kingdoms, while their place is taken by tourists, to suit whom the public space starts to be adapted to, resulting in the local community feeling like strangers in their own city.

The aim of this article is to assess the attitudes of Kraków residents towards the development of tourism in their city. Here, we verify the hypothesis that the attitudes of residents depend on the degree to which they are engaged both in providing services for tourists and in earning an income from such involvement, as well as their place of residence in relation to the districts most frequented by tourists. The authors' intention is also to apply the results to the G.V. Doxey Irritation model as well as R.W. Butler's Tourism Area Life Cycle (TALC) concept, both of which assume a change in residents' attitudes relative to an increase in the density of tourist traffic.

\section{Literature Review}

\subsection{Overtourism as a Factor in Unsustainable Development}

Scientific literature proves that the first use of the term overtourism dates back to the beginning of the 21st century, when it was used to describe the danger of excessive exploitation of natural resources [9]. Later, the term 'turismofobia' appeared in the Spanish media to describe the reaction of Barcelona residents to the excessive growth of tourism [10]. The notion of tourist saturation was also used to describe excessive saturation of destinations due to tourism. It must be added that the phenomenon is nothing new, as the issue has been the subject of discussion in academic circles for many years. As early as the 1970 's, special indicators were developed to define the optimal size of tourist traffic for various regions. The literature mentions three basic measurements: absorption indicator, capacity indicator, and flow indicator [11,12]. Meanwhile, Butler published a theory on the evolution cycle of tourist areas (TALC) [13], and Doxey constructed an irritation index illustrating the change in residents' attitudes to tourists [14].

Due to the frequent perception of the negative impact of tourism development, it has become necessary to adopt new scientific terminology. Therefore, the term overtourism has come to be used to describe the negative effect of tourism and has been applied to the problem of excessive numbers of tourists in many cities. The discussion around overtourism has brought attention to the negative consequences of the unchecked increase in tourism. It also points to possible limitations and voluntary compromises aimed at effectively preventing an increase of such problems [15].

In the last two years, the magazine Sustainability has published many articles on the topic of overtourism. An excellent review of the literature on this problem was presented by Capocchi, Vallone, 
Pierotti, and Amaduzzi [16], collating over eighty texts using bibliometric research. Meanwhile, in their description of the rights of travelers and residents, Perkumien and Pranskuniene [17] also conducted a review of the already abundant literature related to overtourism.

A variety of regulations and formal restrictions on the reception of tourists can be put in place by local authorities or even by the governments of host countries [18]. Reports are appearing in the media of attempts to limit tourist traffic by limiting tourist numbers. In 2019, in Venice, entrance fees to the city were introduced. The phenomenon of overtourism has been studied in many European cities such as Madrid and Palma de Mallorca [19], and its effects have been described in relation to Krakow [8,20] and Ljubljana [7]. Excessive numbers of tourists are observed in many port cities thanks to cruise tourism [21]. However, research in 13 European cities such as Amsterdam, Berlin, Copenhagen, Lisbon, and Tallinn indicates abuse of the term 'overtourism' (overtourism overused) and seven myths attributed to this phenomenon [22].

Overtourism applies not only to cities but also to areas valuable in terms of nature, especially national parks, reserves, mountains, and polar regions. The authorities in the Philippines have decided to close the paradise island of Boracay for six months to clean the beaches and allow the natural environment to regenerate. Similar action was taken by Thailand with regard to the famous Maya Bay beach on Phi Phi Leh island. Overtourism also occurs in national parks, e.g., in the USA and Europe [23].

\subsection{Conceptual Research Framework on the Opinions of Residents and Tourists and the Development of a Tourist Region}

There are also alternative research concepts, such as the Limits of Acceptable Change-(LAC), which allow for the assessment of the degree to which the effect of tourism can be accepted by local parties interested in its development [24,25]. In periods of increased financial need, residents may have a more tolerant attitude and endure the negative effects of tourism due to the potential economic benefits. Discussion on the LAC concept and other similar approaches has meant that instead of using figures to illustrate the mass scale of tourist traffic, emphasis has been placed on qualitative analysis balancing the benefits and drawbacks of the development of tourism [26]. Various approaches to tourism management have also appeared that go beyond the limits on the number of visitors. The first, supported by the UNWTO, focuses on increasing the tourist capacity in reception areas [1]. Capacity can be increased through, amongst others, the use of intelligent hi-tech solutions or by increasing acceptance in the local community and stimulating entrepreneurship [27]. Other approaches focus on the need to diversify forms of tourism and the building of proper relations between the interested parties involved in tourism. Attention should be drawn to the fact that the benefits and drawbacks are often not evenly distributed among the interested parties [28].

The TALC model (Butler, 1980) and to a lesser degree the Irridex Model (Doxey, 1975) have provided a theoretical framework for many studies, although their popularity has been decreasing in recent years $[29,30]$. The majority of researchers assume in both these models that the large number of tourists associated with the last stages in tourism development have a tendency to generate unfavorable or negative attitudes amongst residents [31].

An excellent illustration of the change in the attitude of residents towards tourists is the Doxey index, published in 1976 [14,32]. The appearance of negative attitudes among residents towards tourists is a result of the social carrying capacity limits being exceeded, that is, the inability to accept changes as they take place. G.V. Doxey describes the change in residents' attitudes towards tourism at four successive levels, illustrated in Figure 1.

1. The level of euphoria: People are enthusiastic and thrilled by tourism development. They welcome the stranger and there is a mutual feeling of satisfaction. There are opportunities for locals, and money flows in along with the tourist. 
2. The level of apathy: As the industry expands, people begin to take the tourist for granted. The tourist rapidly becomes a target for profit-taking, and contact on the personal plane begins to become more formal.

3. The level of irritation: This will begin when the industry is nearing the saturation point or is allowed to pass a level at which locals cannot handle the numbers without the expansion of facilities.

4. The level of antagonism: Irritation has become more overt. People now see the tourist as the harbinger of all that is bad (e.g., 'Taxes have gone up because of the tourists'; 'They have no respect for property'; 'They have corrupted our youth'). Mutual politeness has now given way to antagonism and the tourist is 'ripped off'.

5. The final level: People have forgotten that what they originally cherished was what drew the tourist, but in the scramble to develop, they overlooked this and allowed the environment to change. What they now must learn to live with is the fact that their ecosystem will never be the same again. They might still be able to draw tourists but of a very different type from those they welcomed in earlier years. If the destination is large enough to cope with mass tourism, it will continue to thrive.

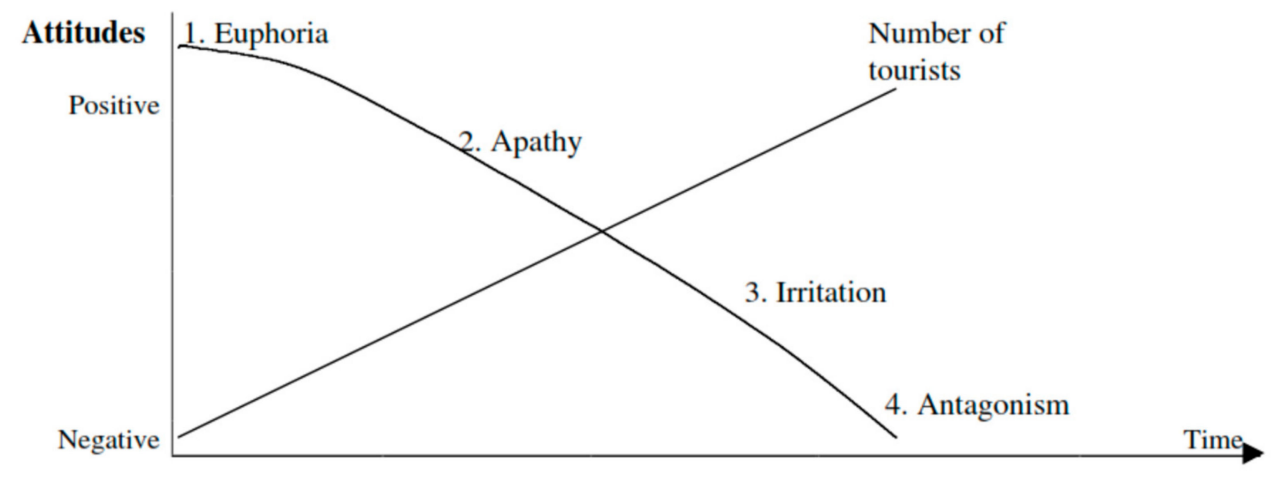

Figure 1. Source: Doxey [29] pp. 26-27.

The Doxey Index has been used to assess the attitudes of residents towards tourists and tourism in Dubai, a city in the Middle East that has experienced dramatic growth in the tourist industry [33]. This research indicated that the tourism industry can continue to develop in the city without causing antagonism amongst the residents. Similar research into the socio-cultural effects of tourism development has been conducted at Balaton Lake in Hungary [34] and on the island of Mauritius [35].

R.W. Butler, who formulated the TALC model (Tourism Area Life Cycle), introduced the evolutionary cycle of a tourist region based on six phases of development of a tourist region (exploration, investment, development, consolidation, stagnation and decline or revitalization), which form a repeating cycle (Figure 2). 


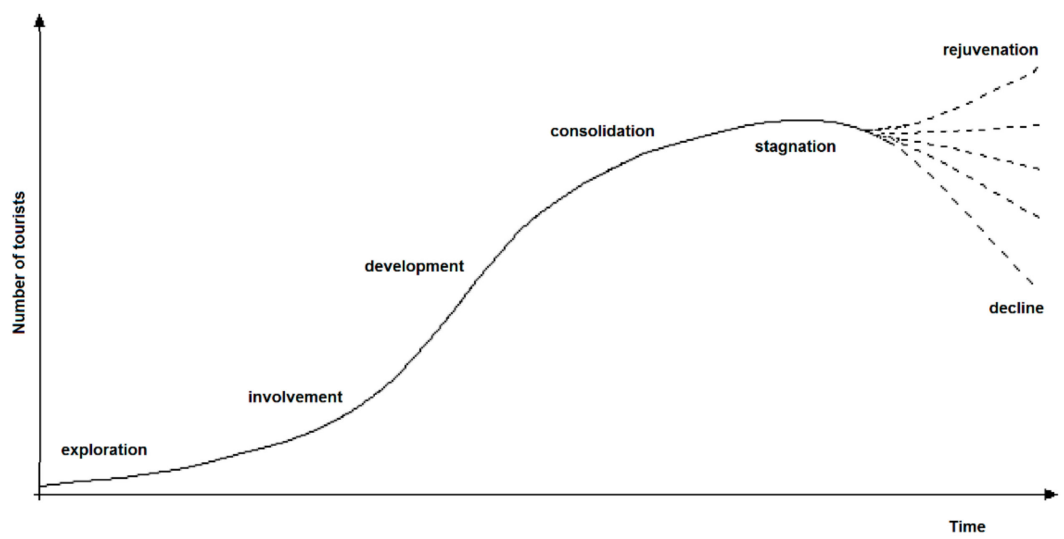

Figure 2. Phases in the Butler cycle in relation to protected areas (Source: [13] (pp. 5-12).

This model is based primarily on a symptomatic variable, that is, the number of visitors to the studied tourist region within one year. R.W. Butler [36] defines sustainable tourism as tourism that is developed and maintained in such a way and on such a scale as to be profitable for an indefinite time, without causing changes to the natural environment in which the tourist region is located. Exceeding the level of 'sustainability' makes the success of development and other undertakings and processes impossible. A certain modification to the TALC model for protected areas such as national parks was then developed by Weizenegger [37]. This assumed that in protected areas, e.g., national parks, limits on tourist traffic can be implemented through the imposition of high taxes for exceeding the region's capacity. This measure is intended to support the aim of protecting the area. In this case, development in such an area would be limited to the first three phases in the Butler cycle, followed by a forced consolidation phase held at the end level of the development phase (Figure 3). This model has been confirmed in relation to the development of tourism in Antarctica [38].

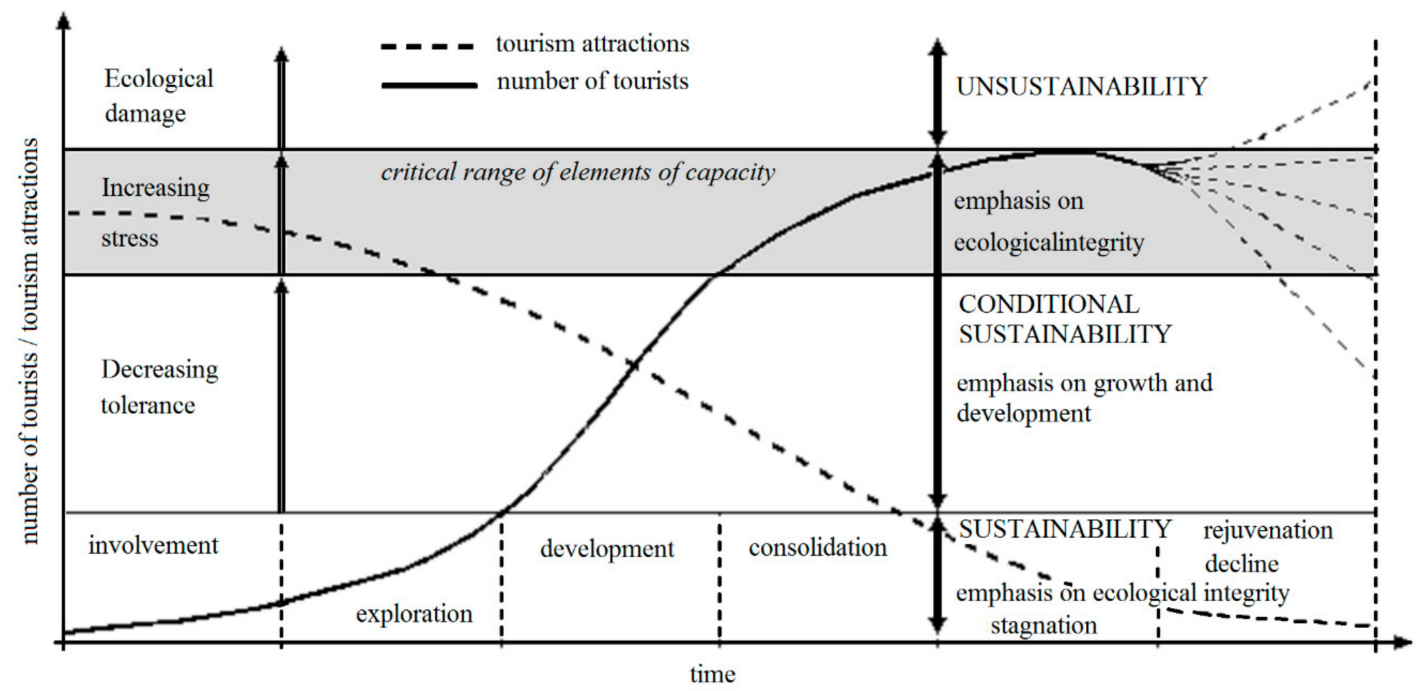

Figure 3. Sustainable development and TALC (Tourism Area Life Cycle). (Source: author's calculations based on: [34,35] (pp. 119-138)).

\section{Materials and Methods}

This article deals with the issue of tourism development in cities, a topic often studied by researchers [39]. To achieve the aim of the article, empirical research had to be carried out to verify the questions and assumptions posed. The study was conducted amongst randomly selected residents 
and amongst businesspeople whose business activity was connected with tourism in Kraków, one of the most frequently visited cities in Central Europe.

Kraków is one of the most recognizable Polish tourist destinations and has been included among tourist metropolitan regions. The Old Town in Kraków and the Wieliczka Salt Mine were added in 1978 to the first World Heritage List of Culture and Nature. Kraków was the European Capital of Culture in 2000. It belongs to the UNESCO Creative Cities Network, was, in 2013, honored as the UNESCO City of Literature, and the European Gastronomic Academy chose Kraków as the European Capital of Gastronomy Culture in 2019. Tourism in Kraków has a very important economic function. In 2018, Kraków was visited by as many as 13.5 million people. In the same year, tourists spent almost 6.5 billion PLN during their stay in Kraków, and the GDP generated by the tourist industry in Kraków is over $8 \%$ of the city's total GDP. Tourism provides Kraków with 29,000 permanent jobs, and taking into account multiplier effects, generates over 40,000 jobs in total [40].

In 2019, Kraków had 780,000 inhabitants and was divided into four main administrative districts, further sub-divided into smaller districts. Together, these 18 small districts, according to the Polish National Territorial Division Register (TERYT), form four main districts: Stare Miasto, Podgórze, Krowodrza, and Nowa Huta. The most attractive district for tourists is the Old Town (Stare Miasto), which covers the historical urban space of the old town including the royal castle (Wawel), the former Jewish district of Kazimierz, as well as numerous churches and museums. The district principally contains hotels, apartments, restaurants, clubs, theatres, and so forth. This district is also the most affected by tourist traffic, with a visible dramatic rise in the provision of short-term tourist accommodation, resulting in gentrification.

The second district is Podgórze, which was a separate town 200 years ago. It is connected to the city center by bridges and walkways and is slowly absorbing part of the tourist traffic. Recently, several prestigious museums have been opened here, e.g., Schindler's Factory. The third district, which borders the city center to the west, is Krowodrza, a district of parks, gardens, sports facilities, and residential areas. The last and largest district is Nowa Huta, a town built in the social realist style as a dormitory for workers at the huge metalworks. The social realist urban layout of Nowa Huta is a reminder of the city's communist era history and is unique in Europe. The district is highly attractive for tourists interested in post-communist heritage [41].

The research method employed was based on a questionnaire distributed to a randomly selected sample of representatives of Kraków. A common feature of all those included in the study was permanent residence in one of Kraków's four main districts or the running of tourist sector business activity within this area.

The research questionnaire contained nine detailed questions. The initial part of the questionnaire included questions that first classified the respondent as belonging to a specific research group (residents/businesspeople) and then to a sub-group. For businesspeople, the sub-groups were created using the criteria of type of business activity (hostelry, gastronomy, other tourist services). For city residents meanwhile, the participants were classified into a sub-group according to their place of origin and whether they worked in the tourist industry. The respondents were also classified as belonging to one of the four main city districts (Stare Miasto, Krowodrza, Podgórze, Nowa Huta). The second part of the questionnaire included questions aimed at assessing the impact of tourist traffic on individual districts in Kraków and on the daily lives of city residents and people conducting business activity there.

Respondents were also asked to express themselves on specific attitudes and opinions using respondent compliance assessment with regard to proposed diagnostic statements concerning the degree of disturbance caused by tourism within Kraków (according to the methodology proposed by Doxey [14]). An assessment scale was used, so that respondents could choose one of five symmetrically distributed answer options in terms of the positive or negative effect on residents. Selecting the middle answer indicated a neutral attitude to the issue in question, or a lack of opinion on the topic. For some questions, the answers received were quantified, so that a positive answer to a particular phenomenon 
was given the value 2, or 1 when the positive answer was only partly supported. For negative scores, the value given was -2 unless the answer was only partly negative, in which case it was given the value -1 . A neutral answer was given the value 0 . Therefore, an average score above zero for a specific answer type indicated a positive response to the issue. Meanwhile, a negative average value indicated a negative response among respondents overall to a specific issue.

A summary of the average results of residents and businesspeople made it possible to compare the answers given using non-parametric statistical tests. The results are presented in general in the form of the mean arithmetic score value, with the standard deviation $\left(\mathrm{x}_{\mathrm{Av}} \pm \mathrm{SD}\right)$, and sometimes also with the median value (Me).

In some of the questions used to assess the degree of tourist traffic disturbance in an area, it was also necessary to use a broader point scale, from $0-10$. In the interpretation of the results, the assumption was made that tourist traffic disturbance rated between 0 and 5 constituted disturbance that did not exceed the area's critical level of tourist capacity and absorption, however, a score of 6 to 8 indicated a negative influence of tourist traffic on the local population. A score of 9 or 10 indicated a disturbance that not only worsened relations between tourists and residents but also damaged tourism as a whole in the area studied, leading to its gradual decline. The interpretation methodology applied was taken from the TALC concept [13].

After initial verification of the questionnaires, the answers from the 518 respondents were selected for further analysis, which exceeded the minimum random sample size, estimated to be 386 questionnaires (for an applied level of maximum statistical sample error $\pm 5 \%$ and a reliability score of $p=0.95)$.

The data collected were analyzed using statistical analysis, both one-dimensional (in the form of descriptive analysis), and two-dimensional (in the form of analysis of pair dependence for characteristics of respondents) [42]. In some cases, the significance level of differences between the average values obtained was also assessed. For the comparison of two groups with a different distribution of variables to normal, the $U$ (Mann-Whitney) test was used [43]. The significance of differences between structural indicators was tested using a Chi-squared test. Verification of statistical hypotheses was conducted using statistical tests, assuming a significance level of $\alpha \leq 0.05$ [44].

Analysis of the research questionnaire was conducted using the alpha Cronbach method (for an assumed limit value of 0.7 ) and showed that the questionnaire has a high reliability score $[45,46]$. In terms of the question on the impact of tourism on daily life in the districts, the alpha Cronbach score was 0.86 , while for the problems observed in the city, the correspondence of respondents' answers was even higher (the alpha Cronbach factor reached a value of 0.94 ). Somewhat different indications were given for the general impact of tourist traffic, as although the reliability of questions regarding the impact on the city and region gave an alpha Cronbach of 0.78 , at the level of the district it was lower. This, however, is the result of considering the impact of tourism jointly for all four districts, in which a differing level of impact was observed. When each district is taken separately there is a similarity in responses, but at a lower level than for other questions. For example, for the key district of Stare Miasto, the test reliability was 0.72 . Overall, the reliability of the questionnaire used can be considered as high, which is the result of initial research that tested the reliability of the research tool.

\section{Research Results}

A total of 518 respondents took part in the research, including 371 city residents (71.6\%) and 147 businesspeople (28.4\%). Among the participating businesspeople, a fifth provide hotel services $(19.9 \%)$, and every thirteenth provided gastronomy services (7.8\%). Of the businesspeople, $72.3 \%$ provided various tourist services (mostly these were businesspeople providing a range of complementary services to hostelry and gastronomy). Among the residents, half were under 35 years old $(51.0 \%)$, $35.6 \%$ of respondents were between 36 and 55 years old, while every seventh was over 55 years old.

More than half of the participants worked in the tourist sector (51.0\%). Over half (56.6\%) also stated that they were originally from Kraków. As regards respondents' place of residence, most 
questionnaires were returned from the Stare Miasto district (44.0\%), which is the principal tourist district in the city. The remaining districts were represented in comparable proportions (from $17 \%$ to $20 \%$ ) (Table 1).

Table 1. Respondent structure. (Source: based on own study.).

\begin{tabular}{cccc}
\hline \multicolumn{4}{c}{ Respondent Structure } \\
\hline Businesspeople & $\mathbf{2 8 . 4 \%}$ & Residents & $71.6 \%$ \\
\hline Type of activity & \multicolumn{4}{c}{ Age } \\
\hline Hotel services & $19.9 \%$ & up to 35 years old & $51.0 \%$ \\
Gastronomy services & $7.8 \%$ & $36-55$ years old & $35.6 \%$ \\
Other tourist services & $72.3 \%$ & over 55 years old & $13.4 \%$ \\
District & \multicolumn{2}{c}{ Work in the tourist sector } \\
\hline Nowa Huta & $17.3 \%$ & Yes & $56.6 \%$ \\
Podgórze & $20.9 \%$ & No & Kraków origin \\
Stare Miasto & $44.0 \%$ & Yes & $54.8 \%$ \\
\hline Krowodrza & $17.8 \%$ & No & $45.2 \%$ \\
\hline
\end{tabular}

Assessment of the impact of tourist traffic on participants was conducted in three place categories. The first was the district where the respondents lived or ran their business. The second was the city, and the third was the region. This division made it possible to evaluate answers about the effect of tourism on these three categories separately.

Respondents' assessments of the amount of tourist traffic at the district level, expressed on a scale of 1 to 10 , showed an optimal level of traffic at around $5\left(x_{\mathrm{Av}}=5.49 \pm 2.81 ; \mathrm{Me}=5\right)$. However, this is the average score of four separate districts, and it is worth noting that only one district displayed optimal traffic, while the rest are either overburdened by tourism (as in the case of the old town-Stare Miasto $\left(\mathrm{x}_{\mathrm{Av}}=7.43 \pm 2.4 ; \mathrm{Me}=8\right)$ ), or have an insufficient number of tourists, such as Krowodrza and Nowa Huta, where tourists are still expected in larger numbers than at present $(\mathrm{Me}=4)$.

In terms of the assessment of tourist traffic at the city level, the average score given by respondents was $\mathrm{x}_{\mathrm{Av}}=7.57 \pm 1.97(\mathrm{Me}=8)$. This means, therefore, that Kraków is struggling with an excess of tourists, but to a moderate degree. Assuming that tourist traffic assessed at between 0 and 5 is a level that does not exceed the critical level of capacity and absorption, it can be said that Kraków has exceeded the limit of tourist capacity, a conclusion that is reflected in the answers of city residents. At the same time, it must be underlined that this is not yet a level that damages the tourism industry in the city, but it does place a burden on residents to a moderate or excessive degree.

However, it must be emphasized that a respondent's direct opinion of tourists does not reflect negative attitudes towards problems caused by tourist traffic in the city. Participants had a moderately positive assessment of the tourists visiting the city $\left(\mathrm{x}_{\mathrm{Av}}=6.57 \pm 2.44\right)$. However, analysis of the results obtained by district shows a varying attitude towards tourists. The lowest results $\left(\mathrm{x}_{\mathrm{Av}}=6.1\right.$ \pm 2.78 ) were noted in the main tourist district-Stare Miasto. At the same time, the average level of respondents' comfort of life in the city was assessed at $\mathrm{x}_{\mathrm{Av}}=6.32 \pm 2.27$, while in the Stare Miasto district it is even lower $\left(\mathrm{x}_{\mathrm{Av}}=5.44 \pm 2.61\right)$, both in relation to the overall result and to the other districts.

In terms of the impact of tourist traffic on the region, respondents showed the lowest divergence of opinion. The impact on the region was assessed to be at the mid-point level between the impact on the city and on the districts and hovered around the moderate level at $x_{A v}=6.26 \pm 2.01$. This is therefore a higher result than the impact on individual districts (with the exception of Stare Miasto), but is lower than the assessment of the impact on the city as a whole. This may mean that the impact on the city is assessed from the perspective of the impact on the main tourist district, in this case, Stare Miasto.

It is also interesting that respondents' origin, whether it be from the city or from outside the city, had no effect on their assessment of the comfort of life, nor on their expressed attitude towards 
tourists or their assessment of the impact of tourist traffic on the city $(p>0.05)$. A respondent's place of employment in tourism or outside the sector not only had an influence on their attitude towards tourists $(p<0.001)$, which would appear to be understandable, but also on their assessment of the impact of tourist traffic on the city $(p<0.001)$.

In terms of the differences between the assessment of residents and that of businesspeople providing tourist services in the city, significantly differing scores can be seen for all of the variables analyzed. While businesspeople displayed a lower level of comfort in running their business than the comfort of city life for residents $(p=0.029)$, in the case of their attitude towards tourists, businesspeople returned a significantly higher assessment than residents $(p<0.001)$. As far as the impact of tourist traffic on the city is concerned, it is worth noting that residents reported a significantly higher impact than did businesspeople $(p<0.001)$. This is understandable, however, given that businesspeople received income from tourist traffic, while only every second survey respondent was engaged in the tourism industry.

The results obtained on the attitude of residents towards visiting tourists was verified using a model of changes in residents' attitudes towards tourists according to Doxey [14]. To this end, residents were asked to indicate which attitude corresponds to their attitude towards tourists. The model was also supplemented with an extreme attitude as included in the Doxey model, but not named by him. This expresses a complete deterioration of tourism in the area under study, and thus was referred to as decline. During analysis of the results obtained in this area, it can be seen that the answers of the majority of respondents who reside in Kraków districts indicate the first two phases of the Doxey model (that is euphoria and apathy). These phases are indicated by almost exactly the same percentage of respondents (Figure 4). One exception is the district of Stare Miasto, where just under half of respondents chose the attitude euphoria, but which at the same time has the highest percentage of people who indicate their attitude as antagonism (13.6\%). The youngest district in the city, Nowa Huta, has the best results, but it is also the city district which experiences the lowest impact of tourism.

When the research results are applied to the Doxey model, they show the highest level of negative indicators among residents and businesspeople in the Stare Miasto district, where there is the highest concentration of tourist traffic. Taking into consideration the recommended measurement of the phenomenon of excessive tourism, it can be safely hypothesized that there is a link between the level of acceptance and the features of overtourism [47].

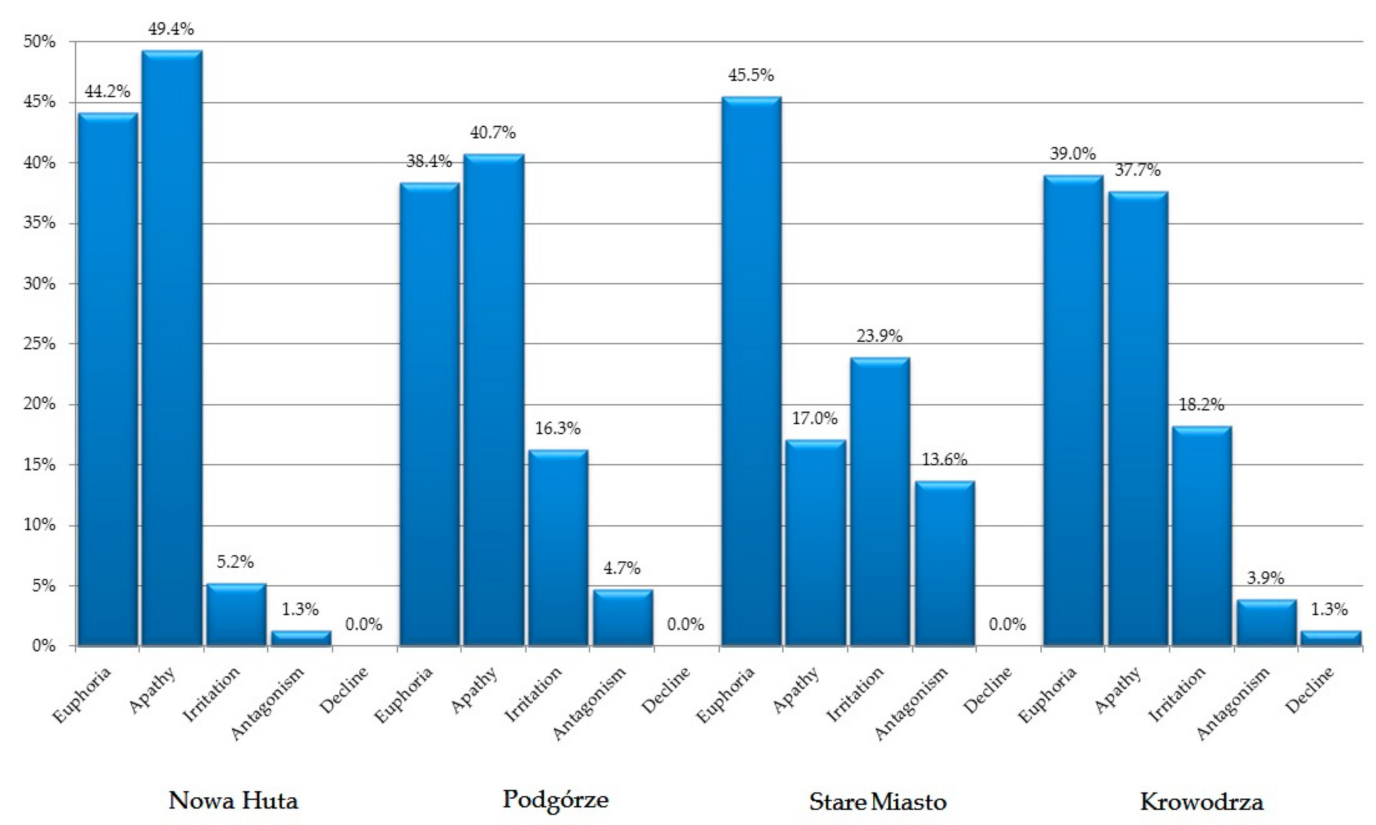

Figure 4. Comparison of the attitudes of residents and businesspeople in the main districts of Kraków. (Source: own study). 
Detailed results of the attitudes indicated are presented in Table 2. It is worth noting the differences in the attitudes of residents and businesspeople conducting business activity in the city. While every third resident indicated their attitude to be one of euphoria, expressed in the following terms: $I^{\prime} m$ happy that tourists come to visit because that means income for the city, new contacts, jobs, prestige ... (33.8\%), this attitude was selected by as much as twice as many businesspeople (71.9\%).

Among residents, 9.4\% of people expressed their attitude as one of conflict, expressed in the following way: At the moment, tourists mainly just cause problems. There are too many of them, which means a lower comfort of life for residents. Something should be done about it, e.g., introduce limit, meanwhile, only $2.1 \%$ of businesspeople expressed the same opinion.

Table 2. Average scores according to the Doxey model. (Source: own work).

\begin{tabular}{|c|c|c|c|c|c|}
\hline General & Nowa Huta & Podgórze & Stare Miasto & Krowodrza & TOTAL \\
\hline $\begin{array}{l}\text { I'm happy that tourists come to visit } \\
\text { because that means income for the city, } \\
\text { new contacts, jobs, prestige }\end{array}$ & $44.2 \%$ & $38.4 \%$ & $45.5 \%$ & $39.0 \%$ & $42.5 \%$ \\
\hline $\begin{array}{l}\text { It's natural that tourists come to visit } \\
\text { our city. It has no real effect on me. We } \\
\text { should show our hospitality ... }\end{array}$ & $49.4 \%$ & $40.7 \%$ & $17.0 \%$ & $37.7 \%$ & $31.7 \%$ \\
\hline $\begin{array}{l}\text { Unfortunately I see more negative than } \\
\text { positive aspects of tourists coming to } \\
\text { my city. }\end{array}$ & $5.2 \%$ & $16.3 \%$ & $23.9 \%$ & $18.2 \%$ & $17.8 \%$ \\
\hline $\begin{array}{l}\text { At the moment, tourists mainly just } \\
\text { cause problems. There are too many of } \\
\text { them, which means a lower comfort of } \\
\text { life for residents. Something should be } \\
\text { done about it. }\end{array}$ & $1.3 \%$ & $4.7 \%$ & $13.6 \%$ & $3.9 \%$ & $7.7 \%$ \\
\hline $\begin{array}{l}\text { I simply cannot tolerate having tourists } \\
\text { in my surroundings! }\end{array}$ & $0.0 \%$ & $0.0 \%$ & $0.0 \%$ & $1.3 \%$ & $0.2 \%$ \\
\hline \multicolumn{6}{|c|}{ Residents } \\
\hline $\begin{array}{l}\text { I'm happy that tourists come to visit } \\
\text { because that means income for the city, } \\
\text { new contacts, jobs, prestige }\end{array}$ & $43.4 \%$ & $36.4 \%$ & $25.0 \%$ & $32.8 \%$ & $33.8 \%$ \\
\hline $\begin{array}{l}\text { It's natural that tourists come to visit } \\
\text { our city. It has no real effect on me. We } \\
\text { should show our hospitality ... }\end{array}$ & $50.0 \%$ & $41.6 \%$ & $20.0 \%$ & $41.8 \%$ & $36.9 \%$ \\
\hline $\begin{array}{l}\text { Unfortunately I see more negative than } \\
\text { positive aspects of tourists coming to } \\
\text { my city. }\end{array}$ & $5.3 \%$ & $16.9 \%$ & $33.0 \%$ & $20.9 \%$ & $20.0 \%$ \\
\hline $\begin{array}{l}\text { At the moment, tourists mainly just } \\
\text { cause problems. There are too many of } \\
\text { them, which means a lower comfort of } \\
\text { life for residents. Something should be } \\
\text { done about it. }\end{array}$ & $1.3 \%$ & $5.2 \%$ & $22.0 \%$ & $4.5 \%$ & $9.4 \%$ \\
\hline $\begin{array}{l}\text { I simply cannot tolerate having tourists } \\
\text { in my surroundings! }\end{array}$ & $0.0 \%$ & $0.0 \%$ & $0.0 \%$ & $0.0 \%$ & $0.0 \%$ \\
\hline \multicolumn{6}{|c|}{ Businesspeople } \\
\hline $\begin{array}{l}\text { I'm happy that tourists come to visit } \\
\text { because that means income for the city, } \\
\text { new contacts, jobs, prestige }\end{array}$ & - & $55.6 \%$ & $72.4 \%$ & $80.0 \%$ & $71.9 \%$ \\
\hline $\begin{array}{l}\text { It's natural that tourists come to visit } \\
\text { our city. It has no real effect on me. We } \\
\text { should show our hospitality ... }\end{array}$ & - & $33.3 \%$ & $13.2 \%$ & $10.0 \%$ & $14.6 \%$ \\
\hline $\begin{array}{l}\text { Unfortunately I see more negative than } \\
\text { positive aspects of tourists coming to } \\
\text { my city. }\end{array}$ & - & $11.1 \%$ & $11.8 \%$ & $0.0 \%$ & $10.4 \%$ \\
\hline $\begin{array}{l}\text { At the moment, tourists mainly just } \\
\text { cause problems. There are too many of } \\
\text { them, which means a lower comfort of } \\
\text { life for residents. Something should be } \\
\text { done about it. }\end{array}$ & - & $0.0 \%$ & $2.6 \%$ & $0.0 \%$ & $2.1 \%$ \\
\hline $\begin{array}{l}\text { I simply cannot tolerate having tourists } \\
\text { in my surroundings! }\end{array}$ & - & $0.0 \%$ & $0.0 \%$ & $10.0 \%$ & $1.0 \%$ \\
\hline
\end{tabular}


Respondents were also asked to indicate the key problems connected to the impact of tourist traffic on the city, as well as to assess the strength of their impact and the seriousness of the problem on a scale of $0-5$ (Table 3). Respondents indicated 10 such areas, although while only seven problem areas were identified in Nowa Huta and Podgórze, as many as 16 were identified in the Stare Miasto district.

In general, the biggest problems in the city caused by tourist traffic were a lack of parking spaces $\left(x_{\mathrm{Av}}=3.63 \pm 1.49\right)$, traffic congestion $\left(\mathrm{x}_{\mathrm{Av}}=3.41 \pm 1.47\right)$, high rent $\left(\mathrm{x}_{\mathrm{Av}}=3.31 \pm 1.56\right)$, crowded public transport $\left(\mathrm{x}_{\mathrm{Av}}=3.29 \pm 1.37\right)$, high land prices $\left(\mathrm{x}_{\mathrm{Av}}=3.25 \pm 1.63\right)$, air pollution $\left(\mathrm{x}_{\mathrm{Av}}=3.17 \pm 1.67\right)$ and rubbish $\left(\mathrm{x}_{\mathrm{Av}}=3.04 \pm 1.56\right)$, high prices for services and goods in shops $\left(\mathrm{x}_{\mathrm{Av}}=2.79 \pm 1.52\right)$, as well as excessive noise $\left(\mathrm{x}_{\mathrm{Av}}=2.77 \pm 1.72\right)$, and problems regarding short-term rental $\left(\mathrm{x}_{\mathrm{Av}}=2.72 \pm 1.83\right)$.

Respondents were also asked which areas of their lives were affected by the presence of tourists. An interesting set of results was obtained, which are presented in Figure 2. The most positive effect of tourism was seen to be aspects such as the economic situation (cost of living and income) and satisfaction related to professional and business life, as well as a feeling of pride in being associated with the city. It must be noted, however, that the average score is in general boosted by businesspeople, who returned significantly higher scores with regard to the positive effects $(p<0.05)$. Residents meanwhile returned considerably lower scores on the impact of tourism.

Table 3. Problematic issues in the city caused by tourist traffic. (Source: based on own study).

\begin{tabular}{|c|c|c|c|c|c|}
\hline Problematic Issue for the City & Overall & Nowa Huta & Podgórze & Stare Miasto & Krowodrza \\
\hline lack of parking spaces & $3.63 \pm 1.49 \rightarrow 4$ & $3.26 \pm 1.54$ & $3.54 \pm 1.38$ & $3.91 \pm 1.45$ & $3.49 \pm 1.56$ \\
\hline traffic congestion & $3.41 \pm 1.47 \rightarrow 4$ & $2.76 \pm 1.54$ & $3.14 \pm 1.42$ & $3.77 \pm 1.38$ & $3.51 \pm 1.42$ \\
\hline high rent & $3.31 \pm 1.56 \rightarrow 4$ & $2.63 \pm 1.63$ & $2.75 \pm 1.53$ & $3.89 \pm 1.35$ & $3.29 \pm 1.46$ \\
\hline crowded public transport & $3.29 \pm 1.37 \rightarrow 3$ & $3.27 \pm 1.36$ & $3.3 \pm 1.39$ & $3.21 \pm 1.42$ & $3.53 \pm 1.23$ \\
\hline high land prices & $3.25 \pm 1.63 \rightarrow 4$ & $2.58 \pm 1.71$ & $2.75 \pm 1.62$ & $3.76 \pm 1.51$ & $3.31 \pm 1.42$ \\
\hline air pollution & $3.17 \pm 1.67 \rightarrow 4$ & $3.28 \pm 1.66$ & $3.11 \pm 1.61$ & $3.16 \pm 1.71$ & $3.15 \pm 1.69$ \\
\hline waste pollution (rubbish) & $3.04 \pm 1.56 \rightarrow 3$ & $2.71 \pm 1.52$ & $2.81 \pm 1.55$ & $3.39 \pm 1.52$ & $2.86 \pm 1.59$ \\
\hline $\begin{array}{l}\text { high prices for services and goods in } \\
\text { shops }\end{array}$ & $2.79 \pm 1.52 \rightarrow 3$ & $2.21 \pm 1.52$ & $2.19 \pm 1.36$ & $3.35 \pm 1.43$ & $2.76 \pm 1.41$ \\
\hline excessive noise on the street & $2.77 \pm 1.72 \rightarrow 3$ & $1.94 \pm 1.53$ & $2.16 \pm 1.59$ & $3.61 \pm 1.51$ & $2.35 \pm 1.66$ \\
\hline $\begin{array}{l}\text { problems with short-term rental of } \\
\text { flats }\end{array}$ & $2.72 \pm 1.83 \rightarrow 3$ & $1.86 \pm 1.71$ & $2.3 \pm 1.67$ & $3.41 \pm 1.77$ & $2.49 \pm 1.71$ \\
\hline $\begin{array}{c}\text { depopulation of buildings in the } \\
\text { district }\end{array}$ & $2.41 \pm 1.86 \rightarrow 2$ & $1.13 \pm 1.31$ & $1.75 \pm 1.58$ & $3.48 \pm 1.72$ & $2.06 \pm 1.63$ \\
\hline high water usage & $2.41 \pm 1.51 \rightarrow 3$ & $2.21 \pm 1.57$ & $2.06 \pm 1.43$ & $2.79 \pm 1.46$ & $2.18 \pm 1.5$ \\
\hline $\begin{array}{l}\text { excessive number of places to drink } \\
\text { alcohol }\end{array}$ & $2.41 \pm 1.77 \rightarrow 2$ & $2.01 \pm 1.62$ & $1.87 \pm 1.55$ & $3.07 \pm 1.79$ & $1.97 \pm 1.63$ \\
\hline safety issues (fights, shouting) & $2.38 \pm 1.62 \rightarrow 2$ & $1.83 \pm 1.43$ & $1.81 \pm 1.33$ & $3.15 \pm 1.58$ & $1.88 \pm 1.52$ \\
\hline noise at night & $2.37 \pm 1.82 \rightarrow 2$ & $1.39 \pm 1.36$ & $1.65 \pm 1.55$ & $3.37 \pm 1.71$ & $1.91 \pm 1.66$ \\
\hline $\begin{array}{c}\text { lack of recreational options in free } \\
\text { time }\end{array}$ & $2.31 \pm 1.59 \rightarrow 2$ & $1.87 \pm 1.48$ & $2.03 \pm 1.47$ & $2.67 \pm 1.65$ & $2.28 \pm 1.54$ \\
\hline no local infrastructure (shops etc.) & $1.92 \pm 1.57 \rightarrow 2$ & $1.27 \pm 1.23$ & $1.58 \pm 1.41$ & $2.43 \pm 1.64$ & $1.79 \pm 1.53$ \\
\hline
\end{tabular}

The only statistically insignificant results were obtained regarding the possibility for residents for religious observance and access to cultural sites $(p=\mathrm{NS})$. For the remaining aspects of the phenomena studied, significantly differing average values were noticed between residents and businesspeople $(p<$ 0.05). Residents more often than businesspeople indicated the negative impact of tourism on city life. One example is the negative impact on transport (in particular parking and getting around the city), as well as the condition of the natural environment in the district and the level of comfort of recreation in free time.

The visual depiction below of the scores given (Figure 5) shows the general attitude of residents and businesspeople towards the impact of tourist traffic on the city. While residents' assessments hover around the 0 mark, that is a neutral attitude towards the impact of tourism, the assessment of 
businesspeople connected with tourism are significantly higher and show a positive effect, but at a moderate level.

\begin{tabular}{l} 
The presence of tourists affects: \\
\hline economic situation (cost of living, income) \\
\hline relationships (family/neighborhood/friends) \\
\hline transport (getting around, parking) \\
\hline comfort of recreation in free time \\
\hline satisfaction from professional/business life \\
\hline access to local infrastructure \\
\hline feeling of safety on the streets
\end{tabular}

Figure 5. The impact of tourist traffic on particular aspects of respondents' lives. (Source: own study).

\section{Discussion}

The research results show varying attitudes among residents towards tourism and tourists, even in the Old Town district most affected by the phenomenon, which confirms previous research conducted by the authors using different methods [47]. The propitious attitude of businesspeople involved in tourism towards visiting tourists is more positive than in the case of residents. However, it must be noted that even in the latter group of respondents attitudes vary. The burgeoning of tourism in the most popular tourist district and subsequent gentrification are becoming a clearly visible phenomenon, although limited in terms of area [8]. The exceeding of the socio-psychological capacity is expressed principally in attitudes towards the difficulty in getting around the city, parking and noise but does not influence parameters such as quality of life and satisfaction from professional life, access to culture, or living costs. In fact, the presence of tourists strengthens residents' pride in the attractiveness of the city. It is worth drawing attention to the results for the district Podgórze, which is boosting its attractiveness for tourists and increasing available accommodation, thus becoming an area that is starting to absorb part of the tourist traffic and whose residents and businesspeople only display an attitude of irritation towards tourism to a very limited degree.

The literature draws attention to the fact that the processes of overtourism and gentrification result in destruction of the socio-cultural fabric of a city, lowering the quality of life, and causing an increasing number of residents to take the decision to move out of the historical city center [47,48]. Gentrification results in a change in the character of a part of the city. In most cases, this is true for districts originally inhabited by local tenants which then become dominated by residents of higher social and material status than the original residents. Kraków as a whole does not have a problem with a drop in the number of residents. However, negative population trends affect the first district, Stare Miasto. Year after year, there is a drop in the number of people registered as permanently resident. This trend has continued uninterrupted since 2004, when the number of those registered was 49,000, while in 2018 there were only 31,600 people registered [8,49]. This is a drop in registered persons of $36.5 \%$ over 13 years. This is partly due to the operation of P2P platforms, in particular AirBnB. In October 2019, the platforms AirBnB and HomeAway had almost 6900 premises available for short-term rental. After Warsaw, this is the second highest amount among all Polish cities, but is lower than direct competitors i.e., Prague and Budapest and the most popular European capitals [48]. In reality, however, when this number is taken in relation to the population of permanent residents, it is shown that the intensity of the phenomenon in Kraków is extremely high. This ratio is almost 9 premises for every 1000 residents, comparable to Prague and Amsterdam, and is higher than the results for cities such as Rome, Lisbon, and Barcelona. The strength of P2P websites is shown in tourist traffic research results 
for Kraków for 2019, according to which 34.1\% of foreigners booked accommodation in the city via booking.com, and 29.7\% via AirBnB [49-51]. Once the former residents have been pushed out, their place is taken by visitors who do not identify with the local community and do not take responsibility for the cultural heritage of the area. For this reason, recommended models have been developed for managing the resilience of cities [52] in terms of the local community, the economy, and infrastructure.

An excessive concentration on specific city districts may lead to an increase in living costs, a reduction in retail options for residents, the transformation of houses and flats into tourists apartments, and other impacts limiting the lifestyle of local residents. Such phenomena can easily be observed in the Kraków Old Town district (together with Kazimierz) and require the development of tools to minimize the effects of the intensification of this process, which as a consequence may lead to the extreme negative stage of P. Russo's [3] vicious circle in the development of tourism, as described in the literature, and a crisis in tourism on the basis of the TALC tourist area life cycle [13]. The results of the study, together with desk research on Kraków tourism statistics, allow for an interpretation of selected criteria for the position of Kraków, as referred to in the models mentioned above.

The level of compatibility of the set of criteria for the decrease in tourism (Table 4) allow for a forecast to be made that also is a result of the specifics of Kraków as a historical medieval city. This forecast suggests that the development of tourist traffic in Kraków will not lead to further expansion of tourism, especially into districts that lie at a greater distance from the city's principal attractions. This will increase the contrast between the geographical distribution of benefits and of costs related to the functioning of the tourism industry in the city overall.

Table 4. Compatibility of criteria with regard to the decline of tourism in Kraków. (Source: own study).

\begin{tabular}{|c|c|}
\hline Tourism Decline Criterion & Compatibility \\
\hline Negative changes in the number of tourists & no \\
\hline Negative changes in the number of overnight stays provided & no \\
\hline Drop in the average length of stay & no \\
\hline The occurrence of seasonality & no \\
\hline $\begin{array}{l}\text { A decrease in the proportion of tourists visiting the city for the } \\
\text { first time }\end{array}$ & no \\
\hline A decrease in the profits of local tourist firms & no \\
\hline A low and decreasing level of accommodation bookings & no \\
\hline $\begin{array}{l}\text { Lack of adequate facilities or infrastructure to meet tourists' } \\
\text { needs }\end{array}$ & no \\
\hline Practical difficulties related to tourist traffic & yes \\
\hline Problems with the local community's attitude towards tourists & yes \\
\hline $\begin{array}{l}\text { An excessive concentration of tourist traffic around main } \\
\text { attractions }\end{array}$ & yes \\
\hline High accommodation prices in the city center & yes \\
\hline A decrease in the profits of firms located in the city center & no \\
\hline Exceeding of tourist attraction capacity & yes \\
\hline A drop in the number of jobs in tourism services & no \\
\hline $\begin{array}{c}\text { Change in the residential profile to one of short-term stays in } \\
\text { some parts of districts }\end{array}$ & yes \\
\hline Rental rates & yes \\
\hline Congestion, noise & yes \\
\hline
\end{tabular}

The research confirms the initial hypothesis put forward. The actual attitudes of Kraków residents depend on the degree of involvement of residents in providing tourist services and obtaining income from such services, as well as on the place of residence in relation to the districts most crowded with tourists in the tourist destination. 
It is also worth noting that the research confirmed that the historical part of the city is currently in the first phase of excessive development of tourism, illustrated by saturation in the supply of tourist sites and accommodation, limited resources (land, buildings, streets, parking spaces, etc.), and the palpable level of irritation in the community. The fact that residents and businesspeople from outside the tourist districts do not experience the side effects of overtourism may also in the long term give birth to conflicts between the city center, which bears the costs of the tourist industry, and neighboring local communities.

\section{Conclusions}

In the process of the further development of tourist traffic, one challenge for historical cities such as Kraków is management of the destination, jointly understood as: an integrated marketing message, dispersion of tourist traffic, easing conflict between residents and visitors or between various groups of competing service providers, regulating access to recognized tourist areas, tools for the gathering of monetary funds, organizational structures, as well as successfully involving residents in providing services for visitors.

The trends and structure of the tourism market require changes in the approach to tourism development from quantity to quality, without disturbing the state of relative balance experienced by residents and the urban space (especially cultural heritage). At the same time, tourist traffic management must quickly and effectively react to changes by implementing the concept of agile tourism, which can be defined as adapting organizational culture and reacting quickly to market changes [53].

The strategic actions proposed by the World Tourism Organization [1], which are intended to combat the negative phenomena associated with modern-day tourism, and the broad analysis of studies conducted for the European Parliament [54], both focus mainly on having an influence on tourist traffic. Only few recommendations relate to communication with residents. However, the opinions and attitudes of residents expressed in our research point to the necessity for intensive dialogue with local interested parties.

This action should, however, cover two distinct areas, (1) minimizing the negative attitude towards tourism and creating conditions for engaging a broader section of the local community in providing tourism and tourism-related services, and (2) minimizing the conflicts between businesspeople that arise as a result of changes in the supply model [53]. The resulting consensus between residents and local service providers regarding development of the city through tourism should have the effect that each group accepts the loss of part of their individual benefits for the good of common values for the city community as a whole, which should also make it possible to achieve the principles of sustainable development. The greater the conflict between interested parties, the more difficult it will be to manage the city as a tourist destination, and the greater the risk of the decline in not only tourism, but also of the tourist reputation of the city.

One answer to the problems that occur as a result of expansion of the tourism industry is most certainly responsible tourism. Goodwin [54] held that responsible tourism tackles the socio-economic and environmental problems and opportunities which arise as a consequence of tourism activities. He notes the need to drive toward socially and economically responsible tourism, environmental responsibility, ecotourism, and conservation.

The necessity of building positive relations via responsible tourism is also indicated by Camilleri [55]. His paper demonstrates that the real essence of responsible tourism lies in the implementation of laudable behaviours. This may be the direction indicated by Hall [56], who emphasizes that responsible behaviours transcend attitudes and genuine organisational commitment, not only in policy formalisation. Camilleri indicates that responsible tourism has led to improved relationships with social and regulatory stakeholders, effective human resources management, better market standing, operational efficiencies and cost savings, along with other benefits $[57,58]$. 
Attention is drawn in the latest publications by Milano and all [59] and Dodds and Butler [60] to the problems of measuring the phenomenon of overtourism and implementing solutions to prevent its negative effects. The differences in attitudes among businesspeople are most likely the result of differing business models (e.g., hoteliers, restaurateurs, or businesses involved in the night economy). Achieving unanimous agreement on implementing tools that can limit overtourism would therefore appear to be impossible and would be subject to lobbying by various groups of interested parties.

This research points to a phenomenon of varying perceptions of the weight of traffic in individual districts in a tourist destination. Identification of a variety of behaviours amongst residents and businesspeople in particular districts has provided data on the perception of overtourism among different interest groups. The empirical research cited here has broadened prior knowledge on overtourism in cognitive terms. This includes both issues of the conflicting aims of residents and businesspeople in terms of the expansion of tourism in the city, as well as the differences in the attitude towards the phenomenon from the point of view of residents in key tourist districts and residents of districts not directly connected to tourism. The value added of the research was also the successful use of methodological assumptions in the form of creative methods of measuring the excessive impact of tourist traffic.

Author Contributions: A.R.S. prepared the following elements of the article: the methodology, research tool development, data analysis, research results development, and correction of the entire article. Z.K. and B.W. conducted the literature review, made the conclusions, and conducted the research. All authors have read and agreed to the published version of the manuscript.

Funding: This research received funding from the National Science Center in Poland.

Acknowledgments: This paper was published as part of the research project 'A business model for health resort enterprises' No. 2017/25/B/HS4/00301, supervised and financed by the National Science Center in Poland and as part of statutory research No. 13/990/BK_19/0138 at the Silesian University of Technology. Faculty of Organization and Management.

Conflicts of Interest: The authors declare no conflict of interest. The funders had no role in the design of the study, in the collection, analyses or interpretation of data, in the writing of the manuscript, or in the decision to publish the results.

\section{References}

1. Overtourism? Understanding and Managing Urban Tourism Growth beyond Perceptions; UNWTO: Madrid, Spain, 2018. [CrossRef]

2. Szromek, A. Wskaźniki Funkcji Turystycznych. Koncepcja Wskaźnika Funkcji Turystycznej I Uzdrowiskowej; Wyd. Politechniki Ślaskiej: Gliwice, Poland, 2012.

3. Russo, A.P. The "Vicious Circle" of Tourism Development in Heritage Cities. Ann. Tour. Res. 2002, 29, 165-182. [CrossRef]

4. Lindberg, K.; McCool, S.; Stankey, G. Rethinking Carrying Capactiy. Ann. Tour. Res. 1997, 24, 461-465, 467. [CrossRef]

5. McCool, S.F.; Lime, D.W. Tourism carrying capacity: Tempting fantasy or useful reality? J. Sustain. Tour. 2001, 9, 372-388. [CrossRef]

6. Saveriades, A. Establishing the social tourism carrying capacity for the tourist resorts of the east coast of the Republic of Cyprus. Tour. Manag. 2000, 21, 147-156. [CrossRef]

7. Kušcer, K.; Mihalic, T. Residents' Attitudes towards Overtourism from the Perspective of Tourism Impacts and Cooperation-The Case of Ljubljana. Sustainability 2019, 11, 1823. [CrossRef]

8. Kruczek, Z. Tourists vs. Residents. The Influence of Excessive Tourist Attendance on the Process of Gentrification of Historic Cities on the Example of Kraków. Tur. Kult. 2018, 3, 29-41.

9. Nelson, B. God's Country or Devil's Playground: The Best Nature Writing from the Big Bend of Texas; University of Texas Press: Austin, TX, USA, 2002; ISBN 978-0-292-75580-2.

10. Milano, C. Turismofobia: Cuando el turismo entra en la agenda de los movimientos sociales. Marea Urbana 2017, 1, 5-8.

11. Kostrowicki, A.S. Zastosowanie metod geobotanicznych w ocenie przydatności terenu dla rekreacji i wypoczynku. Przegląd Geograficzny 1970, 42, 631-646. 
12. Canestrelli, E.; Costa, P. Tourist carrying capacity: A fuzzy approach. Ann. Tour. Res. 1991, 18, $295-311$. [CrossRef]

13. Butler, R.W. The concept of a tourist area cycle of evolution: Implications for management of resources. Can. Geogr. 1980, 24, 5-12. [CrossRef]

14. Doxey, G. A causation theory of visitor-resident irritants, methodology and research inferences. The impact of tourism. In Proceedings of the Sixth Annual Conference Proceedings of the Travel Research Association, San Diego, CA, USA, 8-11 September 1975.

15. Russo, A.P.; Scarnato, A. Barcelona in common: A new urban regime for the 21st-century tourist city? J. Urban Aff. 2018, 40,1-20. [CrossRef]

16. Capocchi, A.; Vallone, C.; Pierotti, M.; Amaduzzi, A. Overtourism: A literature review to assess implications and future perspective. Sustainability 2019, 11, 3303. [CrossRef]

17. Perkumenie, D.; Pranskuniene, R. Overtourism: Betwenn the right to travel and residents' rights. Sustainability 2019, 11, 2138. [CrossRef]

18. Jamal, T.; Camargo, B.A. Sustainable tourism, justice and an ethic of care: Toward the Just Destination. J. Sustain. Tour. 2017, 22, 11-30. [CrossRef]

19. García-Hernández, M.; de la Calle-Vaquero, M.; Yubero, C.; García-Hernández, M.; de la Calle-Vaquero, M.; Yubero, C. Cultural Heritage and Urban Tourism: Historic City Centres under Pressure. Sustainability 2017, 9, 1346. [CrossRef]

20. Zmyślony, P.; Kowalczyk-Anioł, J. Urban tourism hypertrophy: Who should deal with it? The case of Krakow (Poland). Int. J. Tour. Cities 2019, 5, 247-269. [CrossRef]

21. Sanz-Blas, S.; Buzova, D.; Schlesinger, W. The Sustainability of Cruise Tourism Onshore: The Impact of Crowding on Visitors' Satisfaction. Sustainability 2019, 11, 1510. [CrossRef]

22. Koens, K.; Postma, A.; Papp, B. Is Overtourism Overused? Understanding the Impact of Tourism in a City Context. Sustainability 2018, 10, 4384. [CrossRef]

23. Balmford, A.; Green, J.M.H.; Anderson, M.; Beresford, J.; Huang, C.; Naidoo, R.; Walpole, M.; Manica, A. Walk on the Wild Side: Estimating the Global Magnitude of Visits to Protected Areas. PLoS Biol. 2015, 13, e1002074. [CrossRef]

24. Lucas, R.C.; Stankey, G.H. Role of Research in Applying the Limits of Acceptable Change System. In Proceedings of the Southern Recreation Research Conference, Myrtle Beach, SC, USA, 28 February-1 March 1985; pp. 1-15.

25. Frauman, E.; Banks, S. Gateway community resident perceptions of tourism development: Incorporating 475 Importance-Performance Analysis into a Limits of Acceptable Change framework. Tour. Manag. 2011, 32, 128-140. [CrossRef]

26. Nijs, V. Resident Attitudes Towards Tourism; Testing the Resident Empowerment through Tourism Scale 481 (RETS) in Bruges. Master's Thesis, MODUL University, Vienna, Austria, 2017.

27. Pearce, P.L. Limiting overtourism the desirable new behaviours of the smart tourist. In Proceedings of the Tourism Intelligence 485 Forum (t-Forum) Global Exchange Conference 2018, Palma de Mallorca, Spain, 11-13 March 2018.

28. Bianchi, R.V. The 'Critical Turn' in Tourism Studies: A Radical Critique. Tourism. Geographies 2009, 11, 484-504. [CrossRef]

29. Martinez-Garcia, E.; Raya, J.M.; Majo, J. Differences in residents attitudes towards among mass tourism destinations. Int. J. Tour. Res. 2017, 19, 535-545. [CrossRef]

30. Nunkoo, R.; Ramkissoon, H. Small island urban tourism: A residents' perspective. Curr. Issues Tour. 2010, 13, 37-60. [CrossRef]

31. Choi, H.; Murray, I. Resident attitudes toward sustainable community tourism. J. Sustain. Tour. 2010, 18, 575-594. [CrossRef]

32. Doxey, G.V. When enough's enough: The natives are restless in Old Niagara. Herit. Can. 1976, 2, $26-27$.

33. Zaidan, E.; Kovacs, J. Resident attitudes towards tourism and tourism growth: A case Study from the Middle East, Dubai in United Arab Emirates. Eur. J. Sustain. Dev. 2017, 6, 291-307. [CrossRef]

34. Ratz, T. Residents' perceptions of the socio-cultural impact of tourism at lake Balaton, Hungary. In Tourism and Sustainable Community Development; Richard, G., Hall, D., Eds.; Routledge: London, UK, 2003.

35. Soper, A.K. Developing Mauritianness: National identity, cultural heritage values and tourism. J. Herit. Tour. 2007, 2, 94-109. [CrossRef] 
36. Butler, R.W. Tourism, environment, and sustainable development. Environ. Conserv. 1991, 18, $201-209$. [CrossRef]

37. Weizenegger, S. The TALC Model and Protected Natural Areas: African Examples. In The Tourism Area Life Cycle, Conceptual and Theoretical Issues; Butler, R.W., Ed.; Channel View Publications: Clevedon, NY, USA; Buffalo, NY, USA; Toronto, ON, Canada, 2006; Volume 2, pp. 124-137.

38. Kruczek, Z.; Kruczek, M.; Szromek, A.R. Possibilities of Using the Tourism Area Life Cycle Model to Understand and Provide Sustainable Solution for Tourism Development in the Antarctic Region. Sustainability 2018, 10, 89. [CrossRef]

39. Edwards, D.; Griffin, T.; Hayllar, B. Urban tourism research: Developing an agenda. Ann. Tour. Res. 2008, 35, 1032-1052. [CrossRef]

40. Kruczek, Z.; Mazanek, L. Krakow as a Tourist Metropolitan Area. Impact of Tourism on the Economy of the City. Studia Peregietica 2019, 26. [CrossRef]

41. Banaszkiewicz, M. A dissonant heritage site visited. The case of Nowa Huta in Kraków. J. Tour. Cult. Chang. 2017, 15, 185-197. [CrossRef]

42. Greenacre, M.; Hastie, T. The Geometric Interpretation of Correspondence Analysis. J. Am. Stat. Assoc. 1987, 82, 437-447. [CrossRef]

43. Stanisz, A. (Ed.) Biostatystyka; Wyd. Uniwersytetu Jagiellońskiego: Kraków, Poland, 2005; pp. $109-409$.

44. Kendall, M.G. Multivariete Analysis; Charles Griffin: London, UK, 1975; pp. 3-198.

45. Cronbach, L.J. Coefficient alpha and the internal structure of tests. Psychometrika 1951, 3, 297-334. [CrossRef]

46. Szromek, A.R. Współczynnik $\alpha$-Cronbacha w badaniach zjawisk turystycznych. Zeszyty Naukowe Uniwersytetu Szczecińskiego Ekonomiczne Problemy Turystyki 2010, 14, 153-161.

47. Peeters, P.; Gössling, S.; Klijs, J.; Milano, C.; Novelli, M.; Dijkmans, C.; Eijgelaar, E.; Hartman, S.; Heslinga, J.; Isaac, R.; et al. Research for TRAN Committee-Overtourism: Impact and Possible Policy Responses; European Parliament, Policy Department for Structural and Cohesion Policies: Brussels, Belgium, 2018.

48. Walas, B. Turystyczny najem krótkoterminowy w ocenie interesariuszy lokalnych, Biuletyn KPZK PAN, Komitet Przestrzennego Zagospodarowania Kraju Polskiej Akademii Nauk. Zeszyt 2019, 275, 45-58.

49. Chrzanowski, M. Barometr Krakowski; Urząd Miasta Krakowa: Kraków, Poland, 2018.

50. Borkowski, K. Badanie Ruchu Tutustycznego w Krakowie; Urząd Miasta Krakow: Kraków, Poland, 2019.

51. Gotham, K.F. Tourism Gentrification: The Case of New Orleans' Vieuxcarre (French Quarter). Urban Stud. 2005, 42, 1099-1121. [CrossRef]

52. Gravari-Barbas, M.; Guinand, S. (Eds.) Tourism \& Gentrification in Contemporary Metropolises: International Perspectives; Taylor \& Francis: Oxfordshire, UK, 2017.

53. Cheer, J.; Lew, A. Understanding Tourism Resilience: Adapting to Social, Political, and Economic Change. In Tourism, Resilience, and Sustainability: Adapting to Social, Political and Economic Change; Routledge Taylor \& Francis Group: Oxfordshire, UK, 2017; pp. 3-17.

54. Goodwin, H. Taking Responsibility for Tourism; Woodeaton Goodfellow Publishers Limited: Oxford, UK, 2011.

55. Camilleri, M.A. Responsible tourism that creates shared value among stakeholders. Tour. Plan. Dev. 2016, 13, 219-235. [CrossRef]

56. Hall, C.M. A typology of governance and its implications for tourism policy analysis. J. Sustain. Tour. 2011, 19, 437-457. [CrossRef]

57. Fang, M.; Nguyen, T.-H.; Armstrong, A. Proceedings of the Conceptual framework to Guide Development and Evaluation of Agile Leadership in Tourism Destinations, Melbourne, Australia, 8 December 2017.

58. Butler, R.W.; Szromek, A.R. Incorporating the Value Proposition for Society with Business Models of Health Tourism Enterprises. Sustainability 2019, 11, 6711. [CrossRef]

59. Milano, C.; Cheer, J.; Novelli, M. Overtourism Excesses, Discontens and Measures in Travel and Tourism; CABI: Walingford, UK, 2019.

60. Dodds, R.; Butler, R. Overtourism Issues Realities and Solutions; De Gruyter: Berlin, Germany, 2019.

(C) 2019 by the authors. Licensee MDPI, Basel, Switzerland. This article is an open access article distributed under the terms and conditions of the Creative Commons Attribution (CC BY) license (http://creativecommons.org/licenses/by/4.0/). 